\title{
Residual Effects of Liquid Digested Sludge on the Quality of Broomsedge in a Pine Plantation
}

\section{S. DUNAVIN AND M. C. LUTRICK}

\section{Abstract}

Broomsedge (Andropogon virginicus L.) is generally looked upon with some disfavor as a weed but has been utilized for grazing. Liquid digested sludge (LDS) has been tested as a fertilizer on tree plantations where broomsedge comprises a portion of the understory. Broomsedge samples were collected 4 years after treatment of a slash pine (Pinus caribaea More.) plantation with LDS containing 0, 21.6, 40.5, 62.1, 83.7, and $102.6 \mathrm{t} / \mathrm{ha}$ of dry solids. Sludge was applied both as a top application and incorporated prior to tree planting. Crude protein (CP) of grass samples was generally increased with an increase in sludge application. In vitro organic matter digestibility (IVOMD) appeared to decrease with increased sludge application under conditions of top application only. The understory at the 0 and $21.6 \mathrm{t} / \mathrm{ha-rates}$ of sludge was about $67 \%$ broomsedge. At the higher sludge rates, the understory was only $10 \%$ broomsedge or less.

Broomsedge bluestem (Andropogon virginicus L.) is found throughout most of the eastern U.S. and in several western states (Hitchcock 1935). Considered a pest, it has been called "Autumn's Golden Glow" for its color changes with the weather and the light (Morris 1978). Voigt (1953) found that about 3 months of satisfactory grazing of broomsedge could be expected in southern Illinois. The grass has been accused of destroying the value of millions of acres of grazing land and hay meadows in the South as a result of encroachment (Thurman and Ward 1967). Broomsedge is not relished by livestock and is usually grazed only in the absence of more palatable grasses (Phillips Petroleum 1956). Considerable effort has been directed toward the control of broomsedge. Peters and Lowance (1974) indicated that fertilization of tall fescue (Festuca arundinacea Schreb.) and bluegrass (Poa pratensis L.) in pastures infested with broomsedge along with mowing of old growth of broomsedge and grazing by cattle resulted in broomsedge control after a period of years. Lowance et al. (1975) indicated the value of certain arsenical herbicides for removing broomsedge from forage grasses. Wolters and Schmidtling (1975) found that intensive culture of pine (Pinus spp.) trees which included clearing, plowing, disking, and 3 post-planting diskings each growing season, with fertilization rates as high as $448-224-224 \mathrm{~kg} / \mathrm{ha}$ of NPK, reduced total broomsedge herbage production in pine plantations.

Land application of sludge has received extensive attention in the last 30 years in the U.S. and England. Anderson (1955) and Bear and Prince (1955) reported beneficial effects from sewage sludge as a fertilizer and soil amendment. Coker (1966) found that liquid digested sludge (LDS) gave as large an increase in grass dry matter as equivalent fertilizers. He found that mean recovery of $\mathbf{N}$ applied in LDS was $84 \%$ of that recovered from equivalent inorganic fertilizer. Lutrick et al. (1976) obtained data indicating that

Authors are associate professor of agronomy and professor of soil science, respectively, Univ. of Florida. Agr. Res. Center, Jay 32565-9524.

This article is Florida Agr. Exp. Sta. Journal Series No. 4302.

Manuscript received November 22, 1982. sun-dried LDS could be fed to cattle at $100 \mathrm{~g} /$ head/day for 219 days without detrimental effects to cattle and with carcasses suitable for human consumption.

Various workers have obtained different results concerning the effect of $\mathbf{N}$ on grasses with regard to digestibility. Niehaus (1971) found in vitro dry matter disappearance (IVDMD) to be unaffected by $\mathrm{N}$ rate on reed canarygrass (Phalaris arundinacea $\mathrm{L}$.). Fribourg et al. (1979) found that fertilization with $\mathrm{N}$ increased the seasonal mean IVDMD of 'Midland' bermudagrass [Cynodon dactylon (L.) Pers.]. Fribourg and Loveland (1978) found that season affected IVDMD of tall fescue more than $\mathrm{N}$ fertilization, although the higher or more frequent $\mathbf{N}$ rates increased IVDMD indirectly. Minson (1973) found that rhodesgrass (Chloris gayana Kunth.), 'Pangola' digitgrass (Digitaria decumbens Stent.), and kikuyugrass (Pennisetum clandestinum Hochst. ex Chiov.) had different responses to $\mathrm{N}$ with respect to digestibility and that the effect of additional $\mathrm{N}$ was not constant throughout the season. Ruelke and Prine (1971) found a significant increase in in vitro organic matter disappearance (IVOMD) in response to levels of fertility for 6 hybrid bermudagrasses, Pangola digitgrass, and 'Pensacola' bahiagrass (Paspalum notatum Flugge).

This study was undertaken to determine the residual effects upon broomsedge of the application of LDS to a pine plantation.

\section{Methods}

Samples of broomsedge were taken on 15 September 1978 from 2 separate experiments which had been established on slash pine (Pinus caribaea More.) plantations. The broomsedge forage samples were taken at random over the plots. Whole plants were clipped to an $8-\mathrm{cm}$ stubble. These samples were ovendried and ground in a Wiley mill. Pine needles were sampled from 6 trees selected at random in each plot. One lateral branch was selected from the south side of each sample tree in the upper half of the crown. The complete needle bundle from the last fully elongated flush of needles on the terminal portion of a primary branch was utilized, and a composite sample of bundles was formed. These were ovendried and ground in a blender. The soil was a Troup loamy fine sand (Grossarenic Paleudult).

Experiment I was planted to pines in February of 1974 and LDS was applied over the trees. Sludge application was completed in November, 1974. In Experiment 2, sludge was applied and incorporated in September, 1974, prior to planting the pine trees on 20 February 1975. Incorporation was done with a rolling chopper. Plots measured $12 \mathrm{~m} \times 37 \mathrm{~m}$. Pine seedlings were planted $1.8 \mathrm{~m}$ apart in rows $3.7 \mathrm{~m}$ apart. Treatments included $0,21.6,40.5$, $62.1,83.7$, and $102.6 \mathrm{t} / \mathrm{ha}$ of dry solids applied as LDS. Sludge was obtained from the Main Street sludge treatment plant in Pensacola, Fla. Each metric ton of dry solids in the LDS contained 33.8 $\mathrm{kg} \mathrm{N}, 17.3 \mathrm{~kg} \mathrm{P}, 1.8 \mathrm{~kg} \mathrm{~K}, 19.0 \mathrm{~kg} \mathrm{Ca}$, and $2.0 \mathrm{~kg} \mathrm{Mg}$. Four replications in a randomized complete block design were utilized.

Sample crude protein (CP), crude fiber (CF), ether extract (EE), and ash were determined on the dried grass samples and CP was determined on the dried pine needles according to the procedures recommended by the Association of Official Analytical Chemists (1970). In vitro organic matter digestion (IVOMD) was determined at the Agronomy Research Support Laboratory in Gainesville, Fla. on the dried grass samples by the 2-stage technique of Tilley and Terry (1963) as modified by Moore et al. (1972). The 
Table 1. Crude protein, crude fiber, ether extract, ash, and in vitro organic matter digestion of broomsedge sampled 4 years after sludge application to a pine plantation.

\begin{tabular}{|c|c|c|c|c|c|c|c|c|c|c|}
\hline \multirow{2}{*}{$\begin{array}{l}\text { Dry solids } \\
\text { Applied as } \\
\text { LDS } \\
\mathrm{t} / \text { ha }\end{array}$} & \multicolumn{5}{|c|}{ Top-application } & \multicolumn{5}{|c|}{ Incorporated } \\
\hline & $\begin{array}{l}\text { S Crude } \\
\text { Protein }\end{array}$ & $\begin{array}{l}\text { Crude } \\
\text { Fiber }\end{array}$ & $\begin{array}{l}\text { Ether } \\
\text { Extract } \\
\%\end{array}$ & Ash & IVOMD & $\begin{array}{l}\text { Crude } \\
\text { Protein }\end{array}$ & $\begin{array}{l}\text { Crude } \\
\text { Fiber }\end{array}$ & $\begin{array}{l}\text { Ether } \\
\text { Extract } \\
\%\end{array}$ & Ash & IVOMD \\
\hline $\begin{array}{c}0 \\
21.6 \\
40.5 \\
62.1 \\
83.7 \\
102.6\end{array}$ & $\begin{array}{l}5.5 c \\
6.1 \mathrm{bc} \\
6.3 \mathrm{~b} \\
6.6 \mathrm{ab} \\
6.6 \mathrm{ab} \\
7.1 \mathrm{a}\end{array}$ & $\begin{array}{l}34.4 \\
35.4 \\
35.4 \\
36.3 \\
36.2 \\
35.6\end{array}$ & $\begin{array}{l}2.1 \\
1.7 \\
1.9 \\
2.1 \\
1.9 \\
1.9\end{array}$ & $\begin{array}{l}3.1 \\
3.2 \\
3.2 \\
2.7 \\
2.9 \\
2.7\end{array}$ & $\begin{array}{l}24.4 \mathrm{a} \\
24.2 \mathrm{a} \\
20.5 \mathrm{~b} \\
20.0 \mathrm{bc} \\
17.2 \mathrm{c} \\
18.6 \mathrm{bc}\end{array}$ & $\begin{array}{l}5.9 c \\
6.5 b c \\
6.7 b c \\
6.7 b c \\
7.4 a b \\
7.9 a\end{array}$ & $\begin{array}{l}35.0 \\
37.0 \\
35.3 \\
34.7 \\
34.3 \\
35.2\end{array}$ & $\begin{array}{l}2.0 \\
2.0 \\
1.9 \\
2.2 \\
2.1 \\
2.1\end{array}$ & $\begin{array}{l}2.5 \\
2.3 \\
2.7 \\
2.4 \\
2.3 \\
2.3\end{array}$ & $\begin{array}{l}24.4 \\
20.8 \\
24.8 \\
22.7 \\
21.5 \\
22.4\end{array}$ \\
\hline
\end{tabular}

Means, in a particular column, followed by the same letter or by no letter are not significantly different at the $5 \%$ level of probability according to Duncan's Multiple Range Test.

data were analyzed statistically by both the analysis of variance and linear regression procedures.

\section{Results and Discussion}

Crude protein concentrations of the broomsedge are shown in Table 1. These data indicate a linear increase in protein with an increase in applied sludge and show that even 4 years after the heavy $\mathbf{N}$ applications there is a residual response.

Although protein content of broomsedge was higher at the higher sludge levels, the value of these areas for possible forage from broomsedge would have been less because the broomsedge stand on the areas with the higher sludge rates (more than $21.6 \mathrm{t} /$ ha of dry solids) was only $10 \%$ or less. Herbage under the pines at the high sludge rates consisted, primarily, of blackberry or dewberry (Rubus $L$. sp.). These are good forages for such game species as deer (Moore 1961).

No differences among sludge treatments were found for IVOMD of broomsedge in the experiment in which sludge was incorporated prior to planting the pine trees; however, in the experiment where sludge was applied over the trees, the IVOMD was significantly $(P<.05)$ higher at the sludge levels of 0 and $21.6 \mathrm{t} /$ ha $($ Table 1$)$. This indicates some decrease in the relative quality of the broomsedge at high levels of sludge under conditions of top-application even though protein content was increased. Of course, these low digestibilities indicate a poor quality forage in all cases.

At the 0-rate of sludge, grass was the major undergrowth herbage component, making up about $70 \%$ of the cover of which about $95 \%$ was broomsedge. In a few areas, Panicum spretum Schult. was abundant.

No differences in CF, EE, or ash content were found for broomsedge among the various levels of sludge (Table 1).

Since the area of the study was a pine plantation, the protein analysis of the pine needles is included and presented in Table 2 and indicates a generally higher protein content with increasing levels of sludge.

These results indicate that $\mathbf{N}$ was available from the sludge even 4 years after application. They also indicate that higher rates of

Table 2. Protein content of pine needles sampled 4 years after sludge application to a pine plantation.

\begin{tabular}{lcc}
\hline \hline \multirow{2}{*}{$\begin{array}{l}\text { Dry solids applied as } \\
\text { LDS }\end{array}$} & \multicolumn{2}{c}{ Crude Protein } \\
\cline { 2 - 3 } / ha & Top-application & Incorporated \\
\hline 0 & $5.2 \mathrm{c}$ & $5.1 \mathrm{~b}$ \\
21.6 & $5.4 \mathrm{bc}$ & $5.2 \mathrm{~b}$ \\
40.5 & $5.8 \mathrm{ab}$ & $5.1 \mathrm{~b}$ \\
62.1 & $5.9 \mathrm{ab}$ & $6.0 \mathrm{a}$ \\
83.7 & $6.3 \mathrm{a}$ & $6.1 \mathrm{a}$ \\
102.6 & $6.2 \mathrm{a}$ & $5.8 \mathrm{a}$ \\
\hline
\end{tabular}

Means, in a particular column, followed by the same letter are not significantly different at the 5\% level according to Duncan's Multiple Range Test. sludge tended to reduce the broomsedge stand with replacement by blackberry or dewberry.

\section{Literature Cited}

Associntion of Omeial Analytical Chemists. 1970. Official methods of analysis (11th Ed.). Association of Official Analytical Chemists, Washington, D.C.

Anderson, M.S. 1955. Sewage sludge for soil improvement. USDA Circ. No. 972.

Bear, F.E., and A.L. Prince. 1955. Agricultural value of sewage sludge. N. J. Agr. Exp. Sta. Bull. 733.

Coker, E.G. 1966. The value of liquid digested sewage sludge I. The effect of liquid sewage sludge on growth and composition of grass-clover swards in Southeast England. J. Agr. Sci. 67:91-97.

Fribourg, H.A., K.M. Barth, J.B. McLaren, L.A. Carver, J.T. Connell, and J.M. Bryan. 1979. Seasonal trends of in vitro dry matter digestibility of $\mathrm{N}$-fertilized bermudagrass and of orchardgrass-ladino pastures. Agron. J. 71:117-120.

Fribourg, H.A., and R.W. Loveland. 1978. Seasonal production, perloline content, and quality of fescue after $\mathrm{N}$ fertilization. Agron. J. 70:741-745.

Hitcheock, A.S. 1935. (Rev. 1951). Manual of the grasses of the United States. 2nd ed. Rev. by Agnes Chase. USDA Misc. Pub. No. 200. p. 763-765.

Lowance, S.A., E.J. Peters, and R.E. Mattas. 1975. Arsenical herbicides for removing broomsedge from forage grasses. Weed Sci. 23:222-223.

Lutrick, M.C., J.E. Bertrand, and H.L. Breland. 1976. The utilization of liquid digested sludge on agricultural land. Soil and Crop Sci. Soc. Fla. Proc. 35:101-106.

Minson, D.J. 1973. Effect of fertilizer nitrogen on digestibility and voluntary intake of Chloris gayana, Digitaria decumbens, and Pennisetum clandestinum. Aust. J. Exp. Agr. Anim. Husb. 13:153-157.

Moore, D.M. 1961. Blackberry, raspberry, and dewberry, Rubus spp. p. 56-57. In: L.K. Halls and T.H. Ripley (ed.) Deerbrowse plants of Southern forests. U.S. Forest Serv. South. and Southeast. Forest Exp. Sta.

Moore, J.E., G.O. Mott, D.G. Dunham, and R.W. Omer. 1972. Large capacity in vitro organic matter digestion procedure. J. Anim. Sci. 35:232 (Abstr.).

Morris, G. 1978. Broomsedge-autumn's golden glow. Prog. Farmer 93:88.

Niehaus, M.H. 1971. Effect of $\mathrm{N}$ fertilizer on yield, crude protein content, and in vitro dry-matter disappearance in Phalaris arundinacea L. Agron. J. 63:793-794.

Peters, E.J., and S.A. Lowance. 1974. Fertility and management treatments to control broomsedge in pastures. Weed Sci. 22:201-205.

Phillips Petroleum Co. 1956. Undesirable grasses and forbs. Sec. 3 of a series. Pasture and Range Plants, p. 8. Bartlesville, Okla.

Ruelke, O.C., and G.M. Prine. 1971. Performance of six hybrid bermudagrasses, Pangola digitgrass, and Pensacola bahiagrass at three fertility levels in North Central Florida. Soil and Crop Sci. Fla. Proc. 31:67-71.

Tilley, J.M.A., and R.A. Terry. 1963. A two-stage technique for in vitro digestion of forage crops. J. Brit. Grassl. Soc. 18:104-111.

Thurman, C.W., and C.Y. Ward. 1967. Broomsedge (Andropogon virginicus L.) as influenced by differential defoliation practices. Proc. Assoc. S. Agr. Workers 64th Annu. Proc.:73. Abstr.

Voigt, J.W.1953. Yields and consumption in a southern Illinois bluegrassbroomsedge pasture. J. Range Manage. 6:260-266.

Wolters, G.L., and R.C. Schmidtling. 1975. Browse and herbage in intensively managed pine plantations. J. Wildl. Manage. 39:557-562. 